\title{
THE COMPETITIVE SAVING MOTIVE: CONCEPT, EVIDENCE, AND IMPLICATIONS
}

Shang-Jin Wei and Xiaobo Zhang

NO. 465

November 2015
ADB ECONOMICS WORKING PAPER SERIES 
ADB Economics Working Paper Series

\section{The Competitive Saving Motive: Concept, Evidence, and Implications}

Shang-Jin Wei and Xiaobo Zhang

No. 465 | November 2015
Shang-Jin Wei (swei@adb.org) is Chief Economist and Director General of the Economic Research and

Regional Cooperation Department, Asian Development Bank.Xiaobo Zhang (x.zhang@cgiar.org) is

Distinguished Professor of Economics at the National School of Development, Peking University, and Senior Research Fellow at the International Food Policy

Research Institute. 
Asian Development Bank

6 ADB Avenue, Mandaluyong City

1550 Metro Manila, Philippines

www.adb.org

(C) 2015 by Asian Development Bank

November 2015

ISSN 2313-6537 (Print), 2313-6545 (e-ISSN)

Publication Stock No. WPS157771-2

The views expressed in this paper are those of the authors and do not necessarily reflect the views and policies of the Asian Development Bank (ADB) or its Board of Governors or the governments they represent.

ADB does not guarantee the accuracy of the data included in this publication and accepts no responsibility for any consequence of their use.

By making any designation of or reference to a particular territory or geographic area, or by using the term "country" in this document, $A D B$ does not intend to make any judgments as to the legal or other status of any territory or area.

Notes:

1. In this publication, " $\$$ ” refers to US dollars.

2. ADB recognizes "China" as the People's Republic of China.

The ADB Economics Working Paper Series is a forum for stimulating discussion and eliciting feedback on ongoing and recently completed research and policy studies undertaken by the Asian Development Bank (ADB) staff, consultants, or resource persons. The series deals with key economic and development problems, particularly those facing the Asia and Pacific region; as well as conceptual, analytical, or methodological issues relating to project/program economic analysis, and statistical data and measurement. The series aims to enhance the knowledge on Asia's development and policy challenges; strengthen analytical rigor and quality of ADB's country partnership strategies, and its subregional and country operations; and improve the quality and availability of statistical data and development indicators for monitoring development effectiveness.

The ADB Economics Working Paper Series is a quick-disseminating, informal publication whose titles could subsequently be revised for publication as articles in professional journals or chapters in books. The series is maintained by the Economic Research and Regional Cooperation Department. 


\section{CONTENTS}

FIGURES

ABSTRACT V V V V V

$\begin{array}{ll}\text { I. INTRODUCTION } & 1\end{array}$

$\begin{array}{ll}\text { II. } & 2\end{array}$

A. Cross-Country Data Patterns 2

B. Household-Level Evidence 2

III. OTHER RELATED STUDIES

$\begin{array}{ll}\text { IV. POLICYIMPLICATIONS } & 7\end{array}$

$\begin{array}{lr}\text { REFERENCES } & 9\end{array}$ 


\section{FIGURES}

\section{FIGURES}

1 Conditional Scatterplot of Sex Ratios and Savings Rates across Economies

2 Prime-Age Sex Ratio and Growth Rate of Number of Registered Companies

3 Five-Year Mortality Rate over Age 50-54 by Cohort and Gender in Taipei,China 


\begin{abstract}
This short essay surveys recent literature on the competitive saving motive and its broader economic implications. The competitive saving motive is defined as saving to improve one's status relative to other competitors for dating and marriage partners. Here are some of the key results of the recent literature: (i) cross-country evidence show that greater gender imbalances tend to correspond with higher savings rates; (ii) household-level evidence suggest that: (a) families with unmarried sons in rural regions with more skewed sex ratios tend to have higher savings rates, while savings rates of families with unmarried daughters appear uncorrelated with gender imbalances; and (b) savings rates of families in cities tend to rise with the local sex ratio; (iii) rising sex ratios contribute nearly half of the rise in housing prices in the People's Republic of China; and (iv) families with sons in regions of greater sex ratios are more likely to become entrepreneurs and take risky jobs to earn more income.
\end{abstract}

Keywords: competition, current account, saving, sex ratio

JEL Classification: D1, E2, F3, I1, J1, J2 


\section{INTRODUCTION}

The competitive saving motive refers to savings for the purpose of raising one's relative status in the competition for dating and marriage partners. Unlike the standard life cycle and precautionary motives for savings, the competitive saving motive is all about competition with others. The higher an individual's savings relative to those in the same age and gender cohort, the better is his/her competitive position.

From an evolutionary point of view, there are good reasons to think that competitive savings can be quantitatively significant. Competitive saving refers to the accumulation of wealth to gain an edge in the race to satisfy one's strong biological and physiological desires. When the competition intensifies, people are willing to adjust their savings rates significantly.

\section{Empirical Motivation and Theory}

We proposed the notion of a competitive saving motive in research published in the Journal of Political Economy in 2011 (Wei and Zhang 2011a). We estimated that a heightened competitive saving motive, triggered by a sharp rise in the People's Republic of China's (PRC) male-to-female ratio in the premarital age cohort since 2000, contributed about $50 \%$ of the actual rise in the Chinese savings rate since 2000. In fact, many economies, including Singapore, India, Viet Nam, the Republic of Korea, and Taipei,China, have also exhibited unbalanced sex ratios in their premarital age cohorts. Accordingly, the competitive saving motive may have played a quantitatively important role in the evolution of these economies' savings rates as well. In addition, the competitive saving motive can still be present and important in economies with a balanced sex ratio, though its effect would not be as easy to estimate, given the lack of variation in the strength of this saving motive.

Du and Wei (2013) formalized a theory of the competitive saving motive. Their model clarified the conditions under which the competitive saving motive at an individual level can translate into major changes in economywide aggregate savings. There are a number of key points from the theory. First, the savings rate of the gender that is in excess supply will tend to rise. With a relative surplus of males, men, and importantly, parents of unmarried sons, will tend to raise their savings whenever the male's probability of marriage goes down. This is because higher savings is considered an effective signal and competitive instrument in the dating and marriage market. Second, the impact on the savings rate of the gender that is in shorter supply is indeterminate. On the one hand, women (and their parents) may wish to reduce their savings to free ride on the higher savings of their future husbands. On the other hand, the desire of women to outcompete each other to be matched with the best possible men could induce them to raise, rather than to lower, their savings rate. Moreover, women may desire to save more in order to maintain "bargaining power" vis-à-vis savings-rich husbands within the marriage. A proiri it is unclear which effect dominates. Third, the economywide savings rate goes up unambiguously in response to a higher sex ratio. This is a striking result and needs some explanation. If women or families with a daughter also raise their savings in response to a higher sex ratio, it is easy to see that aggregate savings would go up. What if they choose to reduce savings? Even in this case, their model predicts that the increase in savings by men or their parents tends to outweigh any reduction in savings by women or their parents, due to a combination of the men's competition motive and their desire to smooth consumption in anticipation of free riding by a future spouse. Fourth, the rise in aggregate savings due to an increase in the sex ratio may be a transitional phenomenon, but the resultant distortions can only be corrected in the long run. 
A rise in the aggregate savings rate that is triggered by a rise in the sex ratio is socially inefficient. While all young men (and their parents) hope to improve their chances of marriage by increasing savings and reducing consumption, such hopes cannot be realized in the aggregate, as the total number of unmarried young men for the country as a whole is ultimately determined by the sex ratio, and not by the aggregate savings rate. The economy thus has excess savings that could be consumed or invested with no corresponding change in the marriage outcome.

In principle, an unbalanced sex ratio in either direction (a surplus of males or a surplus of females) can trigger a rise in the savings rate due to the competitive saving motive. The amount of incremental savings could differ in the two cases if men and women have different tolerances for involuntary singlehood.

\section{EVIDENCE AND FINDINGS}

Empirically, there is abundant evidence that (relative) wealth helps one to gain status in the dating and marriage market. By and large, there are no wealthy men who are involuntary bachelors. Indeed, previous studies have shown that unmarried male portfolio managers are even more likely to take riskier positions or have a less diversified portfolio than their married but otherwise comparable counterparts, presumably to gamble for a higher return.

\section{A. Cross-Country Data Patterns}

Du and Wei (2011) report patterns of gender imbalances and private sector savings rates across countries. Specifically, they run a nonlinear panel regression of the aggregate savings rate on the sex ratio and other control variables, including country and year fixed effects over 1990-2010. The sex ratio is defined as the male-to-female ratio for the premarital age group of 10-24 (from the United Nations Population Division). For robustness, their regressions also controlled for the effects of per capita income, the dependency ratio, the government fiscal deficit, and a proxy for financial development.

Figure 1 plots the (nonlinear) relationship between a country's savings rate and its sex ratio for the cohort of 10- to 24-year olds, after holding constant the control variables. It shows that at sex ratios above $+/-0.5$, greater gender imbalance tends to correspond with higher savings rates. This verifies the theory presented in the Du-Wei model, which predicted that the aggregate savings rate would increase as the imbalance between the genders worsens. However, the increase in the savings rate is stronger when men outnumber women than in the reverse.

\section{B. Household-Level Evidence}

It is useful to go beyond cross-country evidence and examine household-level evidence. We focus on the PRC as it is geographically large and there are significant differences in the extent of gender imbalances across regions. At the national level, the sex ratio for the Chinese premarital cohort increased from near balance in 1990 to about 115 young men per 100 young women in 2007. The PRC's household savings rate (out of disposable income) almost doubled from $16 \%$ to $30 \%$ during the same period. The time series data on the national savings rate and the sex ratio for the premarital cohort clearly move together. 


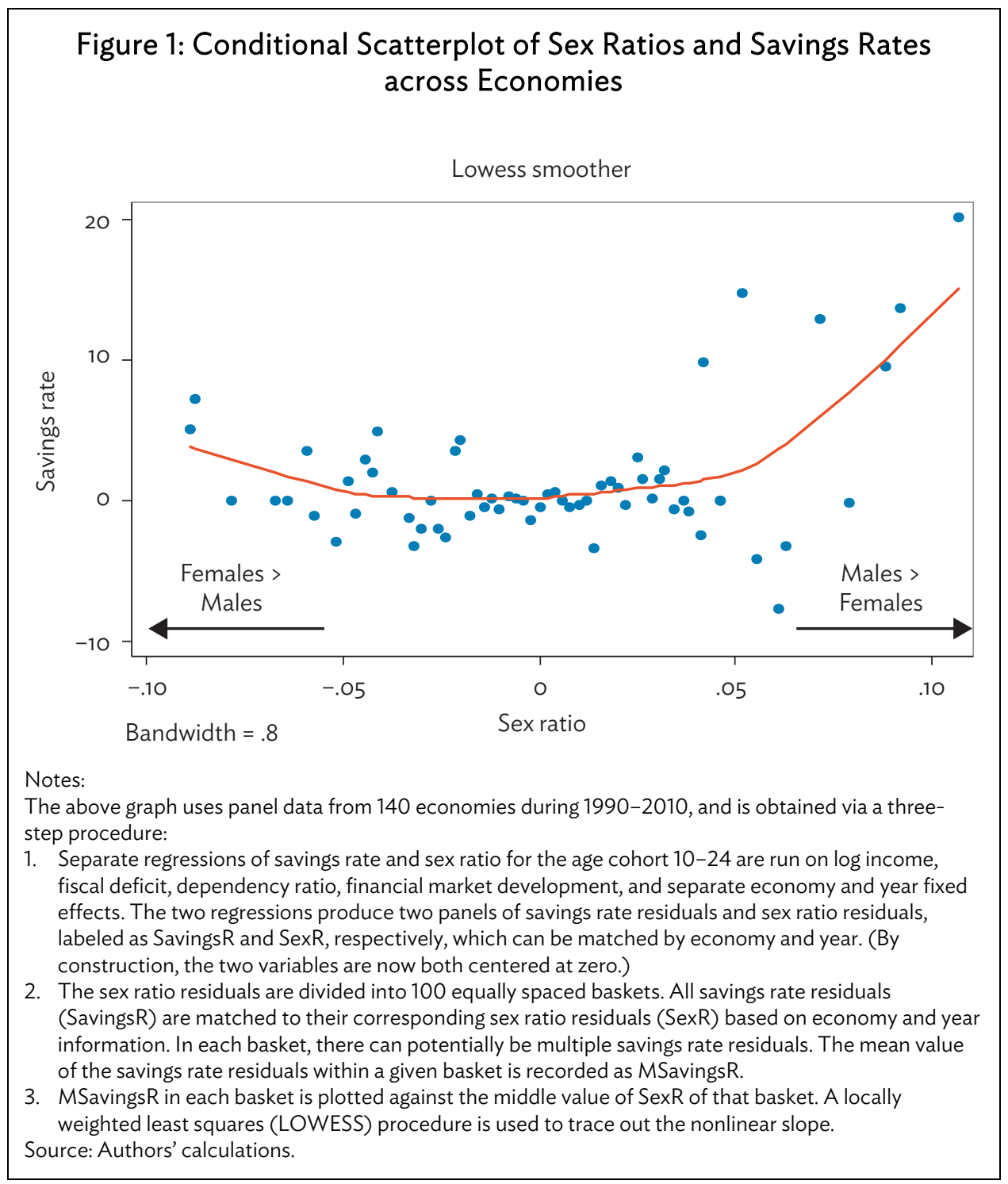

Much as the time series pattern is suggestive, the household-level evidence across regions is even more revealing. While the PRC as a whole exhibits a rising male-to-female ratio, the extent of the gender imbalance is very disparate across the country. For example, Anhui Province has a very unbalanced sex ratio in the order of 120 young men per 100 young women, whereas Inner Mongolia is almost balanced. As the marriage market is very local (i.e., it is uncommon for people to migrate across regions for marriage), we can examine how savings rates respond to changes in local marriage market conditions. The competitive saving motive predicts a particular interaction effect: families with an unmarried son that live in a region with a more unbalanced sex ratio are likely to have a higher savings rate. This pattern is not predicted by standard theories on savings, but can easily be verified in the data.

To examine the empirical relationship between household savings rates (out of disposable income) and local sex ratios (at the county or city level), we run regressions, taking into account other determinants of savings rates such as household income, the age of the household head, gender, ethnicity, educational level, children's ages, and whether family members have major health problems. The interaction effect predicted by our theory is strongly borne out in the data. Wei and Zhang (2011a) 
found that in the rural areas, families with unmarried sons living in regions with a more skewed male sex ratio tended to have higher savings rates. In comparison, the savings rate by families with an unmarried daughter appeared to be uncorrelated with the extent of gender imbalances at the local level. Across Chinese cities, the savings rates by both unmarried son-families and daughter-families tended to rise with the local sex ratio.

These patterns are consistent with the basic prediction of the competitive saving motive: savings tend to be higher in regions with higher sex ratios, especially among families with unmarried sons. The patterns on savings by households with unmarried daughters are also consistent with the Du-Wei model that allows for intrafamily bargaining. When women (or their parents) are concerned about the erosion of bargaining power vis-à-vis their husbands (or his family), they may not reduce their savings rate in response to the gender imbalance. When the effect of intrafamily bargaining dominates, the savings rate by unmarried daughter-families could rise in response to an increase in the number of males to females.

\section{OTHER RELATED STUDIES}

One key motivation for a household to save is to build or purchase a new home for the son's marriage. When the marriage market becomes more competitive, women become choosy and prefer to mate richer men holding everything else constant. Because home ownership is one of the most visible forms of wealth, owning a big and expensive home becomes a status good in the marriage market. Observing women's preference for housing wealth, families with sons compete to build or purchase a new home, preferably bigger and more expensive than their neighbors'. In rural areas, families build homes mainly through private savings. In cities, home buyers must pay a large down payment of at least one-third of the home price. Therefore, in order to build or buy a house, families with sons in regions with more skewed sex ratios must increase their savings to beat other son-families.

Wei, Zhang, and Liu (2015) test the impact of sex ratio imbalances on home ownership and home prices. They use regional variations in the sex ratio of the premarital age cohort across the PRC as a proxy for differential strengths of concern for status. Using data at the household level from the China Population Sampling Survey in 2005, they find that families with sons in areas with more unbalanced sex ratios are more likely to own a home. By linking local sex ratios with housing prices at the city level, they conclude that rising sex ratios contribute nearly half of the rise in housing prices in Chinese cities.

Risky jobs, such as being entrepreneurs, working in coal mines, or committing crimes, normally provide higher pay. If relative wealth status is an important sorting variable in the marriage market, it is expected that when facing more intense marriage market competition, families with sons or single men would be more induced to take riskier jobs in hopes of accumulating quick wealth and moving up the social ladder than those in less competitive regions, while the impact would be more muted for families with daughters.

Roussanov and Savor (2012) find that firms in the United States with single Chief Executive Officers exhibit more volatile stock returns, suggesting that they take greater risks than married Chief Executive Officers. Using data at the provincial level, Edlund et al. (2013) show that elevated sex ratios result in higher property crime rates. The rise in sex ratios account for up to one-seventh of the overall increase in crime in the period 1998-2004. After all, crimes are high-risk and high-payoff activities. 
Wei and Zhang (2011b) find that families with sons in regions of greater sex ratios are more likely to become entrepreneurs and take risky jobs, while families with daughters are not responsive to local sex ratios. However, this study primarily examines parents' responses to the marriage market squeeze due to data limitation. The data used in the analysis is too early to discern the impact, if any, on the one-child generation.

Chang and Zhang (2012 and 2015) make use of a natural experiment in Taipei,China to study the impact of mating competition on entrepreneurship of men in the marriageable age group. After the Kuomintang's defeat, about half a million soldiers, mostly male, fled to Taipei,China from the PRC. Initially they were not allowed to get married; but in 1959, the marriage ban was lifted. With the sudden inflow of half a million young men into the marriage market, the effective sex ratio of men to women of marriageable age became highly skewed overnight. They first imputed prime-age effective sex ratios for different cohorts across counties and then related them to entrepreneurship. Figure 2 plots the time series of sex ratios and extensive growth in number of firms at the aggregate level. The left vertical axis stands for imputed prime-age sex ratios in Taipei,China, while the right vertical axis refers to the 5year moving average of the growth rate of registered companies. As clearly shown in the figure, the two lines mirror each other closely throughout the entire sample period spanning over 55 years. Of course, this figure is simply illustrative and the tentative evidence does not imply any causal relationship. However, using two different data sources at the individual level (i.e., the population census and the elderly survey), they quantitatively show that such a policy change spurred young men's entrepreneurship.

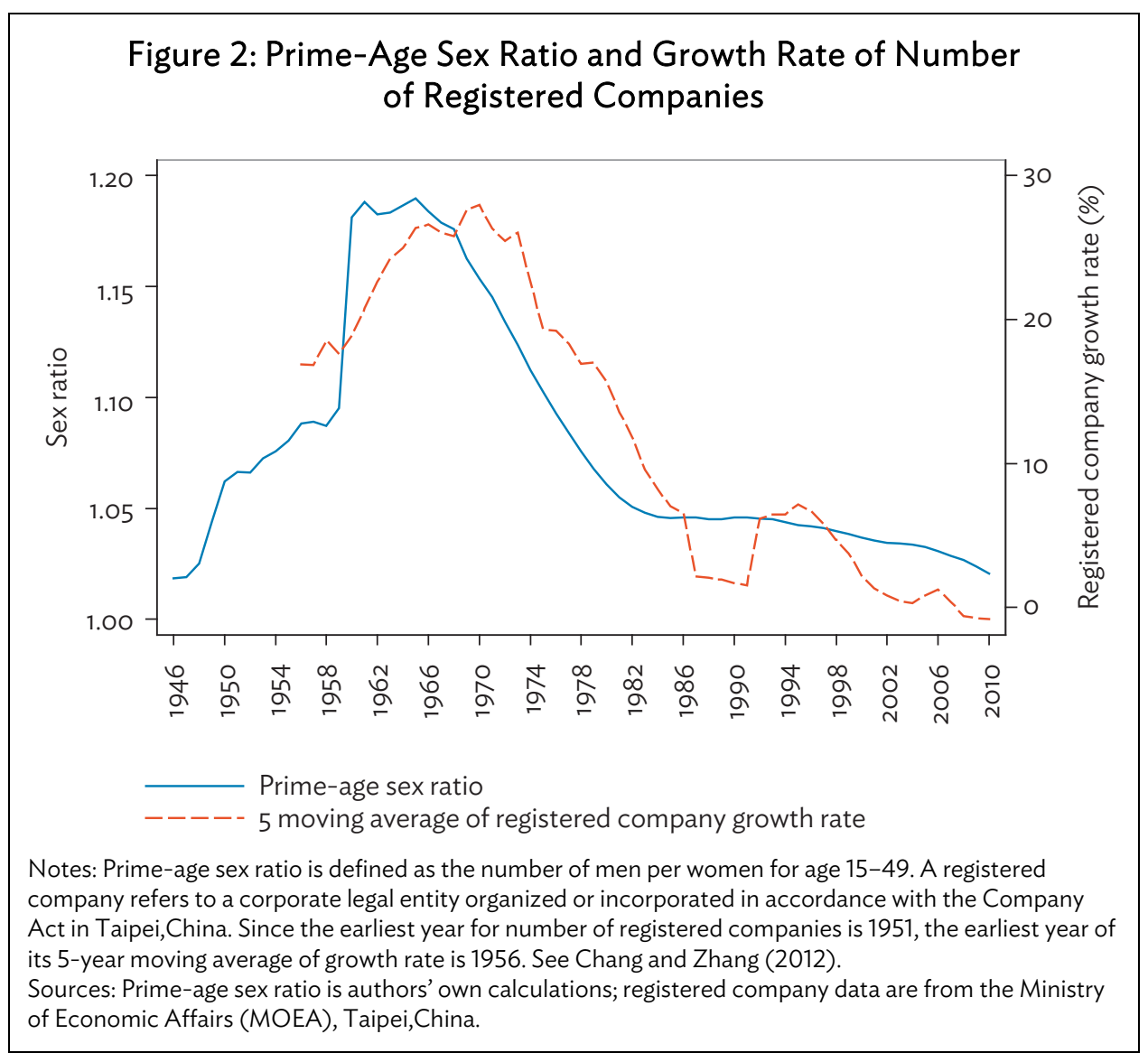


In the earlier version of their paper, Chang and Zhang (2012) find that the marriage market squeeze induced local young men to increase savings, work longer hours, and amass more wealth using multiple datasets.

A few studies have provided evidence that families with sons have incentives to earn more income. Using the China Household Income Project survey, Knight, Shi, and Quheng (2010) show that having a son raises household income by more than $10 \%$. Using nationally representative household data collected in 300 rural Chinese villages, Ding and Zhang (2014) demonstrate that families receive more remittances and invest more in productive activities if the first child is a son rather than a daughter. Indeed, the gender of the first child matters for family finance.

However, as young men or their parents put more effort on work in response to rising sex ratios, they are more likely to stress out. It is well known that stress is an important risk factor for many health problems. Therefore, sex ratio imbalances may have negative health consequences. Using the China Central TV postcard survey, which includes questions on happiness, Tan, Wei, and Zhang (2015) show that higher sex ratios lower people's self-reported happiness. Analyses based on the China Family Panel Survey in 2010 yield consistent findings.

Using the removal of the marriage ban on soldiers (mostly coming from the PRC) as a natural experiment, Chang, Kan, and Zhang (2015) find that the negative impacts of sex ratio imbalances go beyond happiness. As an illustration, Figure 3 displays mortality rates for men and women in age cohort 50-54 according to their birth year. The left and right vertical axes represent 5-year mortality rates for men and women, respectively. For those born before 1935, the difference in mortality rate between men and women is minimal. Given that the average marriage age for men in 1959 was 22 years old, most of them had already gotten married. Therefore, the sudden tightening of the marriage market associated with the removal of the marriage ban in 1959 did not affect the marriage likelihood of men born prior to 1935 . For the cohort born after 1935, male mortality rate figures were much higher than female mortality rates except for 1 year. The cohort born in the period 1936-1950, aged 9-23 in 1959, was subject to more intense mating competition than the older cohort when they entered the marriage market. The figure offers suggestive evidence that higher mating competition in the marriageable age group is associated with greater likelihood of mortality later in life. In the paper, they provide more quantitative evidence in support of the above finding using the Taipei,China Population Census. In addition, they show that men exposed to the policy change displayed a larger likelihood of depression than those who were already married prior to the abolition of the marriage ban based on the Longitudinal Survey of Health and Living Status of the Middle-Aged and the Elderly in Taipei,China for 1996 and 2003. 


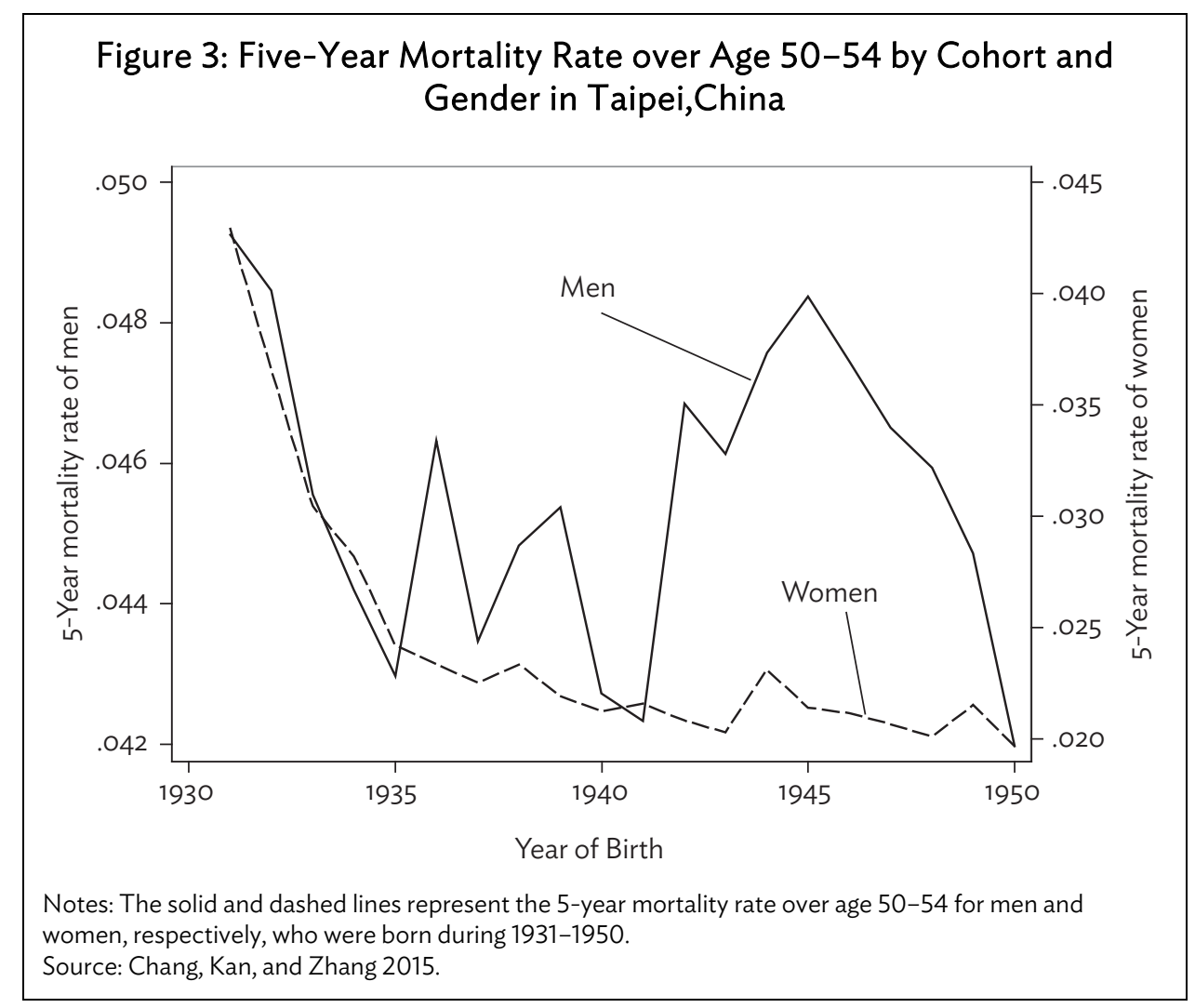

\section{POLICY IMPLICATIONS}

The conventional determinants of savings form only part of the explanation for the high savings rates in Asian economies. New research on the competitive saving motive indicates that a rise in the sex ratio in many of these economies may have played an important role in sustaining the high savings rates, or elevating them to new heights in recent years.

High savings rates play a role in shaping the PRC's economic growth path. More savings mean more investment, which is a key engine of economic growth. As households save excessively, they end up with less money for consumption. The phenomenon of competitive savings probably contributed to the PRC's unbalanced growth model.

By extension, the sex ratio imbalance is a "missing" fundamental variable underlying many of these economies' current account surpluses, since a country's current account is the difference between national savings and investment. The work by Du and Wei (2011) has highlighted that a oneoff increase in the sex ratio can cause a temporary rise in the current account. The latter will shift to the long-run equilibrium level when all cohorts in society have adjusted fully to the new male-to-female ratio. Nonetheless, the transition period can be as long as a decade. If, instead of a one-off increase, there is a sustained rise in the sex ratio, as is the case in the PRC, the phase of the economy's current account surplus could last even longer. If a large country such as the PRC runs a surplus when competitive saving motives are heightened, the rest of the world has to collectively run a current account deficit during the transition period. 
While the sex ratio imbalance is a type of distortion, it is very different from those associated with nominal exchange rate policies, which tend to be the overwhelming focus of typical policy discussions. Gender imbalances exacerbate the competitive saving motive, which may have created an impression of undervaluation in the real exchange rate even when there is none (Du and Wei 2011). Accordingly, if governments were to artificially appreciate the nominal exchange rate to reduce a current account surplus whose root cause is a rise in competitive savings triggered by a higher sex ratio, they would just be introducing a new distortion rather than resolving existing ones. In this instance, the outcome is Pareto inferior, and the country incurs significant welfare losses. Instead of simply focusing on the nominal exchange rate, the research on the competitive saving motive suggests that a broader look at structural determinants of savings and current accounts may turn out to be more productive and helpful in the long run for policy discussions of global imbalances and their correction.

Moreover, overcompetition in the marriage market may bring about negative consequences on the health outcomes of men or families with sons, including subjective welfare and mortality. The adverse effect to a large extent offsets the positive effect on savings and economic growth. Unfortunately, the dark side of competition as a result of increased sex ratio imbalances has not been recognized in both the academic literature and the policy circle. 


\section{REFERENCES}

Chang, S., and X. Zhang. 2012. The Economic Consequences of Excess Men. IFPRI Discussion Paper No. 01203. International Food Policy Research Institute. Washington, DC.

2015. Mating Competition and Entrepreneurship. Journal of Economic Behavior \& Organization. 116. pp. 292-309.

Chang, S., K. Kan, and X. Zhang. 2015. The Dark Side of Competition: Gender Differences. Unpublished.

Ding, W., and Y. Zhang. 2014. When a Son is Born: The Impact of Fertility Patterns on Family Finance in Rural China. China Economic Review. 30. pp. 192-208.

Du, Q., and S.-J. Wei. 2011. A Darwinian Perspective on "Exchange Rate Undervaluation." NBER Working Paper No. 16788. National Bureau of Economic Research. Cambridge, Massachusetts; revision requested by the editor of the European Economic Review.

- 2013. A Theory of Competitive Saving Motive. Journal of International Economics. 91 (2). pp. 275-89.

Edlund, L., H. Li, J. Yi, and J. Zhang. 2013. Sex Ratios and Crime: Evidence from China's One-Child Policy. Review of Economics and Statistics. 95 (5). pp. 1520-34.

Knight, J., L. Shi, and D. Quheng. 2010. Son Preference and Household Income in Rural China. Journal of Development Studies. 46 (10). pp. 1786-805.

Roussanov, N., and P. G. Savor. 2012. Status, Marriage, and Manager's Attitudes to Risk. NBER Working Paper No. 17904. National Bureau of Economic Research. Cambridge, Massachusetts.

Tan, Z., S.-J. Wei, and X. Zhang. 2015. Deadly Discrimination: Implications of "Missing Girls" for Workplace Safety. Unpublished.

Wei, S.-J. and X. Zhang. 2011a. The Competitive Saving Motive: Evidence from Rising Sex Ratios and Savings Rates in China. Journal of Political Economy. 119 (3). pp. 511-64.

2011b. Sex Ratios, Entrepreneurship, and Economic Growth in the People's Republic of China. NBER Working Paper No. 16800. National Bureau of Economic Research. Cambridge, Massachusetts.

Wei, S.-J, X. Zhang, and Y. Liu. 2015. Status Competition and Housing Prices. NBER Working Paper No. 18000. National Bureau of Economic Research. Cambridge, Massachusetts; revised and resubmitted to the Journal of Development Economics. 


\section{The Competitive Saving Motive: Concept, Evidence, and Implications}

We introduce the concept of competitive saving, i.e., saving to improve one's status relative to other competitors for dating and marriage partners, and provide evidence of its existence across and within countries. We argue that sex ratio imbalances have driven the competitive saving motive, and have partly accounted for sustained high savings rates in many Asian economies.

\section{About the Asian Development Bank}

ADB's vision is an Asia and Pacific region free of poverty. Its mission is to help its developing member countries reduce poverty and improve the quality of life of their people. Despite the region's many successes, it remains home to the majority of the world's poor. ADB is committed to reducing poverty through inclusive economic growth, environmentally sustainable growth, and regional integration.

Based in Manila, ADB is owned by 67 members, including 48 from the region. Its main instruments for helping its developing member countries are policy dialogue, loans, equity investments, guarantees, grants, and technical assistance. 